\title{
Technologies for Seismic Retrofitting and Strengthening of Earthen and Masonry Struc- tures: Assessment and Application
}

Paulo B. Lourenço

ISISE, Department of Civil Engineering, University of Minho, Guimarães, 4800058, Portugal; email: pbl@civil.uminho.pt

\section{Abstract}

Earthen and masonry structures are usually heavy and do not possess an integral behavior. A consequence of these characteristics, in combination with the adopted materials featuring low tensile strength and ductility, is that such structures often collapse in a quasi-brittle way, with local failures, usually out-of-plane. This paper first addressed the seismic assessment of these structures, by providing some recent shaking table tests and blind predictions. Obvious limitations were found in providing a good estimate of collapse. Subsequently, techniques for retrofitting and strengthening are addressed, with applications shown in a real case study.

\section{Introduction}

Natural hazards have caused a considerable number of disasters in the last decades. According to the World Bank, from 1975 to 2005 the number of natural disasters increased from approximately 100 to more than 400 (Parker et al., 2007). These events lead to important economic impacts (Noy, 2009), deaths and irrecoverable losses due to the collapse of existing masonry buildings. Consequently, earthquakes contribute significantly to these natural hazard disasters. It is predicted that in the current century the total fatalities caused by earthquakes will increase to about $2.57 \pm 0.64$ million (Holzer and Savage, 2013). Recent seismic events caused severe damages to a considerable number of existing masonry constructions, such as the earthquakes in L'Aquila (Italy, 2009) (Augenti and Parisi, 2010), in Canterbury (New Zealand, 2010 and 2011) (Leite et al., 2013) or in Emilia (Italy, 2012) (Penna et al., 2014).

Historic earthen and masonry buildings were built for many centuries taking into account mostly vertical static loads according to the experience of the builder, usually, without much seismic concern. The seismic behavior of ancient masonry buildings is particularly difficult to characterize and depends on several factors, namely the materials properties, geometry of the structure, connections between structural and non-structural elements, stiffness of the horizontal diaphragms and building condition. However, the different masonry types present common features that lead to high seismic vulnerability of these buildings, such as: (a) low tensile strength and ductility of masonry; (b) weak connections between orthogonal walls and between walls and horizontal diaphragms; (c) high mass of the masonry structural elements;
\end{abstract}


(d) flexible horizontal diaphragms; (e) absence of seismic requirements at the time of their construction (Lagomarsino, 2006, Lourenço et al., 2011).

Regarding the out-of-plane behavior of these structures, the low strength/mass ratio of common masonry structures increases their vulnerability in the out-of-plane direction because inertia forces are not restrained due to reduced stiffness and strength of the masonry walls in that direction. Despite the numerous studies carried out so far (a state-of-the-art review is provided by Ferreira et al., 2015 and by Sorrentino et al., 2016), numerous issues are still unresolved and scarce consensus exists amongst experts on the most appropriate methods to use for seismic safety assessment. For this reason, the seismic performance of masonry structures has received great attention in the last decade, mainly for masonry buildings without box-behavior (Lourenço et al., 2011). However, little consensus exists on the most appropriated assumptions and approaches for assessing the seismic safety of unreinforced masonry buildings without box-behavior.

Therefore, the out-of-plane behavior of historic earthen and masonry structures remains, possibly, the most challenging response in case of seismic action. As demonstrated recurrently all over the world by earthquakes, in case of lack of an integral behavior of the building, out-of-plane failure dominates. This is also favored by the fact that many historic buildings possess large spaces inside, with insufficient connections to transverse structural elements. Even if adequate connections between elements can be ensured, e.g. by tying walls, enforcing connections between walls and enforcing wall to floor connections, it is necessary to avoid disintegration of the walls themselves when subjected to out-of-plane actions, especially in case of rubble masonry.

The out-of-plane response of these structures or their local mechanisms, often assumed as macro-blocks with almost rigid behavior that become independent from the global structure is complex. The dynamics of these local mechanisms close to collapse are very sensitive to the seismic input (e.g. frequency contents, duration or directivity of the signal) but also to the structure itself (e.g. boundary conditions). The methods for structural analysis available for this purpose, both for research and engineering applications, are rather different in terms of formulation, input, conceptual complexity and computational efficiency. For these reasons, the results obtained can also vary greatly. This paper considers, first, a blind test exercise on the out-of-plane failure of historic masonry structures, involving prediction, testing and postdiction (Lourenço et al., 2017). This involved about 25 international experts in the field and clearly demonstrates that further developments are needed in the field. Then, one engineering application of seismic safety assessment and strengthening of a historic earthen structure is shown.

\section{Blind test: Out-of-plane shaking testing failure of masonry}

Experts on masonry structures were invited to present their conjectures on the dynamic response of two idealized masonry structures tested on a shaking table and 
subjected to unidirectional ground motion. One structure was constructed of irregular stone and the other of clay-unit masonry with English bond (Figure 1 and Figure 2). The walls of the brick structure were built with perforated brick, and cementbased mortar, whereas the walls of the stone specimen were built with granite stone and lime-based mortar. The configuration of each structure included a single perforated unreinforced wall with a gable, and return walls on both ends. In each structure, an opening was placed in one of the returning walls, resulting in an asymmetry, and consequently, inducing torsional movements. The thickness of the walls was equal to $0.500 \mathrm{~m}$ and $0.235 \mathrm{~m}$ for the stone and brick structure, respectively. Each structure was tested on the LNEC shaking table in Lisbon (Portugal). For details on the shaking table tests, see Candeias et al. (2017).

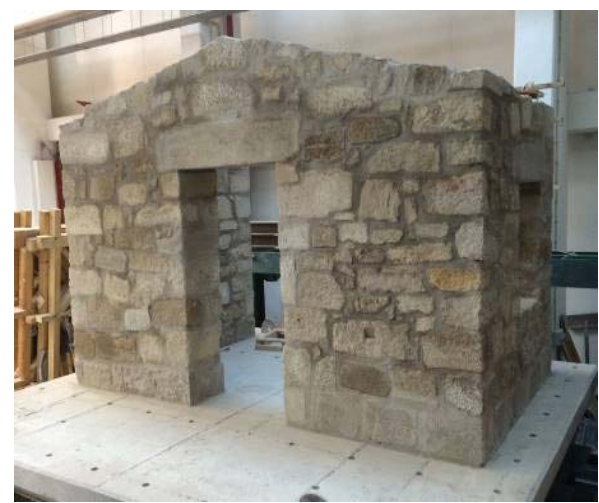

(a)

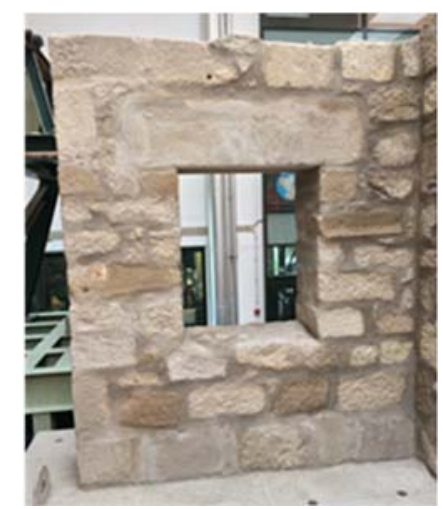

(b)

Figure 1 - Stone structure: (a) general view; (b) return wall with opening.

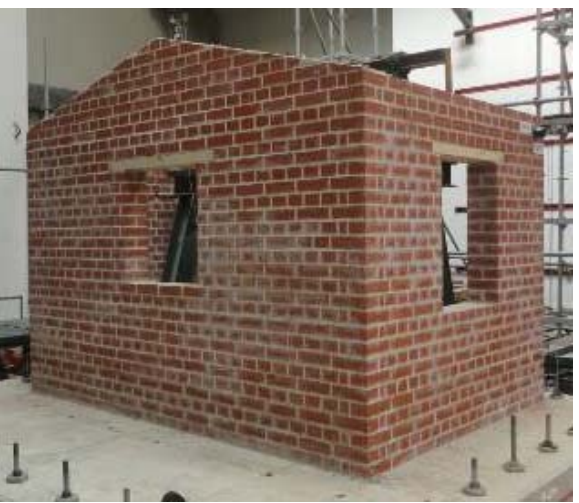

(a)

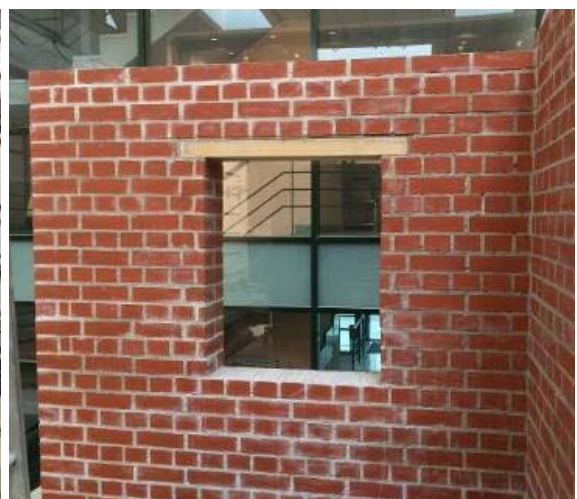

(b)

Figure 2 - Brick structure: (a) general view; (b) return wall with opening. 


\section{Expert results}

The geometry of the structures, the material properties (specific mass, Young's modulus, tensile and compressive strength), the normalized accelerogram envelopes of the seismic action applied at the base, and the corresponding response spectra were provided to the experts. No specific requirements were given to experts in terms of the types of computed results they needed to provide.

The experts presented several modelling approaches, type of structural analysis and assessment criteria for predicting the dynamic behavior of the structures. It is noted that the predictions were made for either or both test structures depending on the expertise of the expert. For details on the predictions of experts, see Mendes et al. (2017) and de Felice et al. (2017).

\section{Predictions}

As an example, the different modelling approaches used are given in Table 1 for the brick structure. A total of 36 predictions of the seismic capacity were made: 17 for the brick structure and 19 for the stone structure. Most predictions were performed with rigid block analysis. Since no information was available on the experimental failure mechanism, blind predictions were based either on personal judgement or on preliminary finite elements or discrete elements models.

Methods based on rigid block analysis represented the mechanism with a singledegree-of-freedom (SDOF) system subjected to the horizontal static loads in addition to the self-weight. The collapse condition was then calculated by equilibrium equations or with the principle of virtual works, with either a static or a kinematic approach. In the static approach, the capacity was estimated as the PGA that activates the mechanism and the demand was derived from the acceleration response spectrum, taking into account the dynamic amplification through the structure and the reserve of stability from the activation of the mechanism to the out-of-plane overturning. In the kinematic approach, the seismic capacity was identified by means of a non-linear analysis, leading to a capacity curve whose ultimate point identified the maximum attainable displacement at collapse. The demand was derived from the displacement response spectrum, calculating a fundamental period of the equivalent SDOF system. One prediction was performed by integrating the equation of motion of a rigid block under earthquake base motion and the PGA was calculated as that inducing instability.

Numerical models with finite elements (FEM, with either macro- or micro-modelling approaches), distinct elements (DEM), or combined finite-discrete elements (FEM/DEM) were used to predict the mechanism and/or to assess the seismic capacity. In finite element macro-models, the masonry was described as an equivalent homogeneous material, while in micro-modelling, the units were represented explicitly and the joints were described by interfaces, where cracking is allowed. Distinct element models considered some representation of the shape of blocks and joints. Differently from limit analysis based approaches, with FEM and DEM the failure mechanism was identified directly by the model. Analyses were either static 
(pushover) under horizontal loads, or dynamic with time-step integration under artificial accelerograms compliant with the response spectrum provided. In the former case (pushover), the capacity was assessed as the peak of the response curve, whilst in the latter, simulations were carried out under increasing intensity of the input (incremental dynamic analysis, IDA) up to a given definition of failure, and the PGA of the last run was taken as the seismic capacity.

Table 1. Example of predictions by experts, for the brick structure (cont.).

\begin{tabular}{|c|c|c|c|c|c|c|}
\hline $\begin{array}{l}\text { Partic- } \\
\text { ipant }\end{array}$ & $\begin{array}{l}\text { Mecha- } \\
\text { nism }^{(1)}\end{array}$ & $\begin{array}{c}\text { PG } \\
\text { A } \\
{[\mathrm{g}]}\end{array}$ & $\begin{array}{l}\text { Modelling } \\
\text { approach }\end{array}$ & $\begin{array}{l}\text { Evalu- } \\
\text { ation } \\
\text { of ca- } \\
\text { pacity }\end{array}$ & $\begin{array}{l}\text { As- } \\
\text { sess- } \\
\text { ment } \\
\text { metho } \\
\text { d }\end{array}$ & Notes \\
\hline \multicolumn{2}{|c|}{ Experimental } & \multicolumn{5}{|l|}{1.27} \\
\hline \multirow[b]{2}{*}{ A } & 2 & 0.30 & $\mathrm{RB}$ & $\begin{array}{c}\text { S } \\
\text { (non- } \\
\text { linear) }\end{array}$ & DB & \multirow{2}{*}{$\begin{array}{l}\text { Failure mechanism identified } \\
\text { by personal judgment. Collapse } \\
\text { displacement predicted through } \\
\text { displacement response spec- } \\
\text { trum. Collapse PGA estimated } \\
\text { through time history analyses. } \\
\text { Postdiction also performed }\end{array}$} \\
\hline & 7 & 0.35 & $\mathrm{RB}$ & $\begin{array}{c}\mathrm{D} \\
\text { (non- } \\
\text { linear) }\end{array}$ & FB & \\
\hline B & 4 & 0.75 & $\mathrm{RB}$ & $\begin{array}{l}\text { S (lin- } \\
\text { ear) }\end{array}$ & FB & $\begin{array}{l}\text { Failure mechanism identified } \\
\text { by personal judgment. }\end{array}$ \\
\hline $\mathrm{C}$ & 2 & 1.00 & $\mathrm{RB}$ & $\begin{array}{l}\text { S (lin- } \\
\text { ear) }\end{array}$ & DB & $\begin{array}{l}\text { Failure mechanism identified } \\
\text { by personal judgment. Collapse } \\
\text { PGA predicted with the capac- } \\
\text { ity spectrum method as that cor- } \\
\text { responding to a spectral dis- } \\
\text { placement equal to } 40 \% \text { of the } \\
\text { instable equilibrium displace- } \\
\text { ment. }\end{array}$ \\
\hline \multirow[b]{2}{*}{$\mathrm{E}$} & 2 & 0.37 & $\mathrm{RB}$ & PVW & FB & \multirow{2}{*}{$\begin{array}{l}\text { Failure mechanism identified } \\
\text { by personal judgment. Collapse } \\
\text { PGA predicted with a force- } \\
\text { based approach that makes use } \\
\text { of the Principle of Virtual } \\
\text { Works, also including dynamic } \\
\text { amplification, or with a dis- } \\
\text { placement-based approach. }\end{array}$} \\
\hline & 2 & 0.39 & $\mathrm{RB}$ & PVW & DB & \\
\hline \multirow[b]{2}{*}{$\mathrm{F}$} & 3 & 0.42 & $\begin{array}{l}\mathrm{FEM} / \mathrm{DE} \\
\mathrm{M}+\mathrm{RB}\end{array}$ & IDA & DB & \multirow{2}{*}{$\begin{array}{l}\text { Failure mechanism identified } \\
\text { by FE model running non-linear } \\
\text { dynamic analyses under artifi- } \\
\text { cial accelerogram. Collapse } \\
\text { PGA predicted on an equivalent } \\
\text { SDOF system with a displace- } \\
\text { ment-based or a force-based ap- } \\
\text { proach. } \\
\text { Postdiction also performed }\end{array}$} \\
\hline & 3 & 0.95 & $\begin{array}{l}\mathrm{FEM} / \mathrm{DE} \\
\mathrm{M}+\mathrm{RB}\end{array}$ & IDA & FB & \\
\hline
\end{tabular}


Table 1. Example of predictions by experts, for the brick structure (contd.).

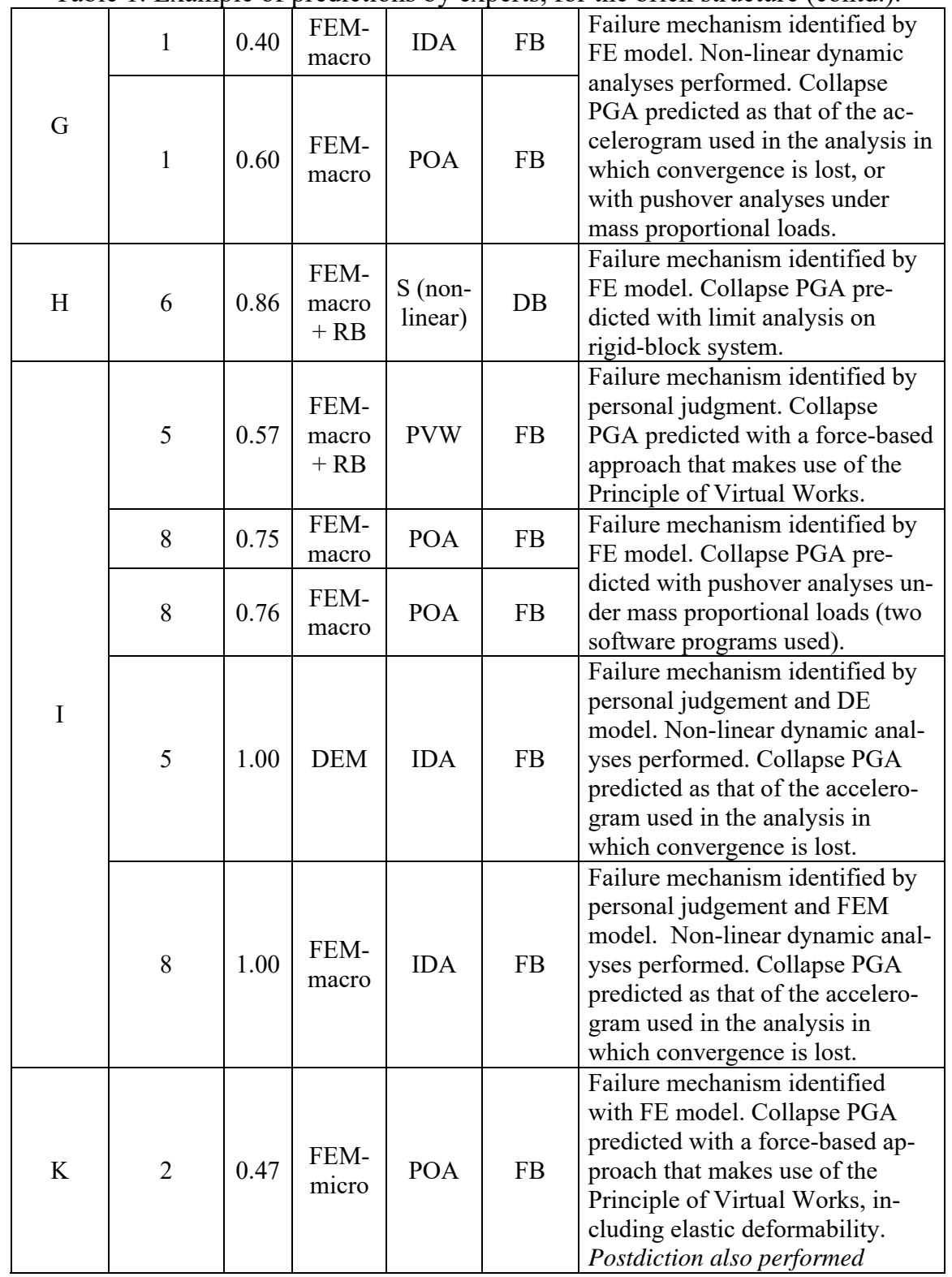

PGA: peak ground acceleration at collapse; RB: limit analysis with rigid-body systems; FEM -micro/-macro: Finite Element Method with micro-/macro- modelling approaches; DEM: Distinct Element Method; S: static analysis; D: dynamic analysis; PVW: principle of virtual works; POA: pushover analysis; IDA: incremental dynamic analysis (time-step integration under earthquake base motion).

(1) (Mendes et al., 2016) for the predicted failure mechanisms and their numbering. 
Failure Mechanisms for Predictions

As an example, eight collapse mechanisms were predicted by the experts for the brick structure, see Figure 3. Predictions varied widely, mainly depending on the assumption by the experts related to (i) the effectiveness of the connections between front and side walls at the corners, (ii) the bending strength of the façade, and (iii) the in-plane strength of side walls. Based on their capability of foreseeing the above features of the experimental failure mechanism, Mendes et al. (2017) assessed as good two (out of 8) failure mechanisms for the Brick House (\#2 and \#7). Predicting the collapse mechanism of the brick structure resulted more challenging than for the stone structure, due to the higher slenderness and flexibility of the walls.

Prediction of the seismic capacity in terms of peak ground acceleration (PGA)

The predictions of the out-of-plane seismic capacity were scattered, which may be considered by itself a demonstration of the scarce consensus amongst researchers on suitable strategies to handle this problem, as well as of the difficulty of the proposed challenge. For the brick structure, the predicted PGAs ranged between $0.30 \mathrm{~g}$ to $1.00 \mathrm{~g}$, with an average of $0.64 \mathrm{~g}(49 \%$ lower than the experimental value) and a Coefficient of Variation (CV) of $39 \%$. If only the good predictions of failure mechanisms are considered, the mean estimate is $0.48 \mathrm{~g}(\mathrm{CV}=50 \%)$, which is worse than the total mean value (Figure 4a). Better predictions were provided for the Stone House on average ( $\mathrm{PGA}=0.91 \mathrm{~g}, 15 \%$ lower than the experimental value), but with a wider range, from $0.22 \mathrm{~g}$ to $2.50 \mathrm{~g}(\mathrm{CV}=64 \%)$. The good predictions of failure mechanism led to a slightly better estimate $(0.93 \mathrm{~g}$ and $\mathrm{CV}=31 \%$, Figure $4 \mathrm{~b})$. Note that the graphs indicate the failure mechanism corresponding to each prediction and the bars of those assessed as good are filled in blue.

Even though identifying the correct collapse mechanism has to be considered fundamental for a reliable estimate of the seismic capacity, the results of the blind test predictions indicate that this is not enough, since the estimated collapse PGAs differed largely and were mostly incorrect even when a common mechanism was assumed. There was no clear relationship between accuracy of the prediction and modelling approach. 
Experimental $(\mathrm{PGA}=1.27 \mathrm{~g})$

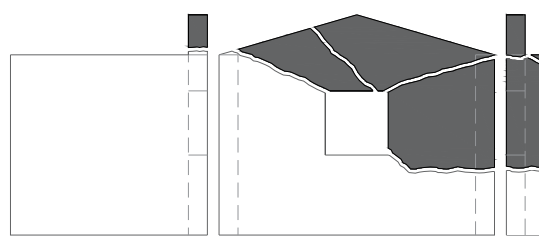

Mechanism 2 (PGA: 0.30g; 0.37g; $0.39 \mathrm{~g} ; 0.47 \mathrm{~g} ; 1.00 \mathrm{~g})$

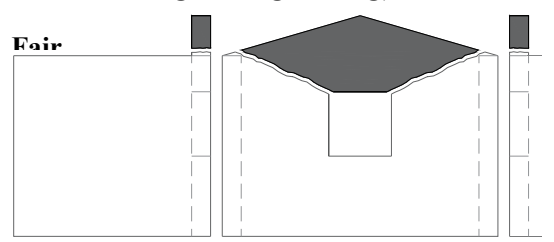

Mechanism 4 (PGA: 0.75g)

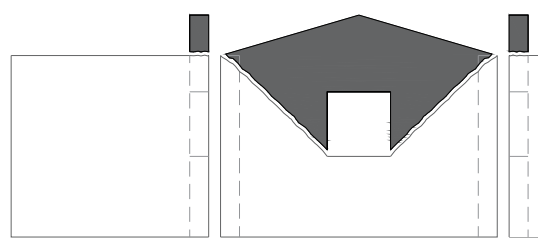

Mechanism 6 (PGA: 0.86g)

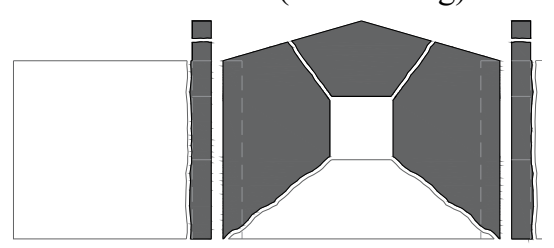

Mechanism 8 (PGA: 0.75g; 0.76g; 1.00g)

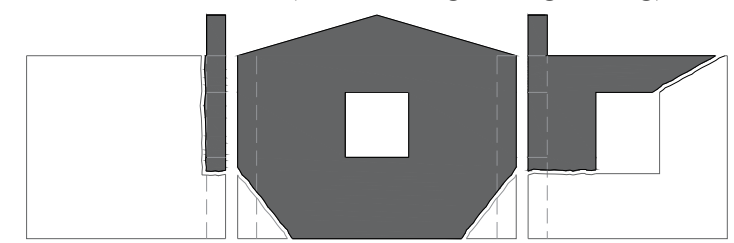

Mechanism 1 (PGA: 0.40g; 0.60g)

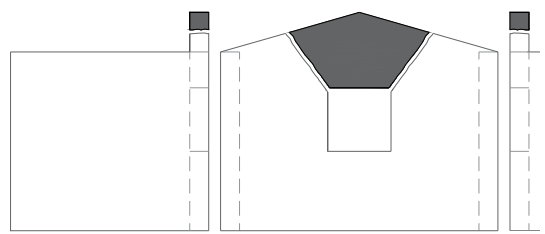

Mechanism 3 (PGA: 0.42g; 0.95g)

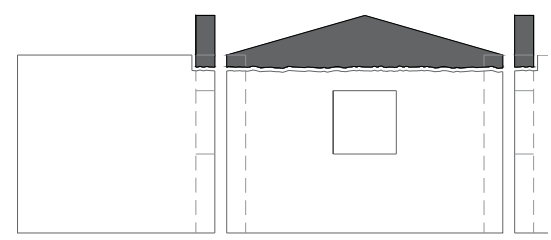

Mechanism 5 (PGA: 0.57g; 1.00g)

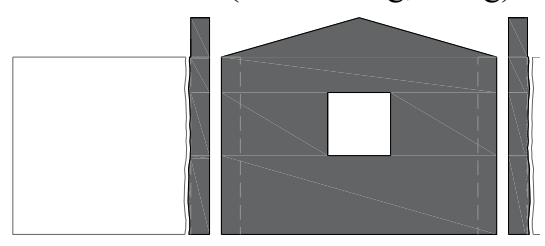

Mechanism 7 (PGA: 0.35g)

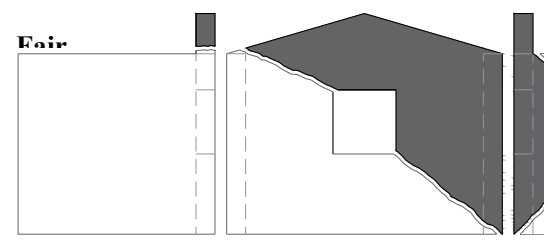

Figure 3 - Idealized expert predicted collapse mechanisms, brick structure. 


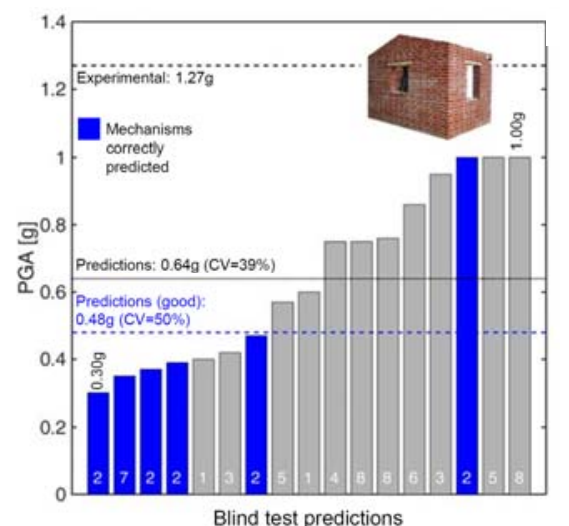

(a)

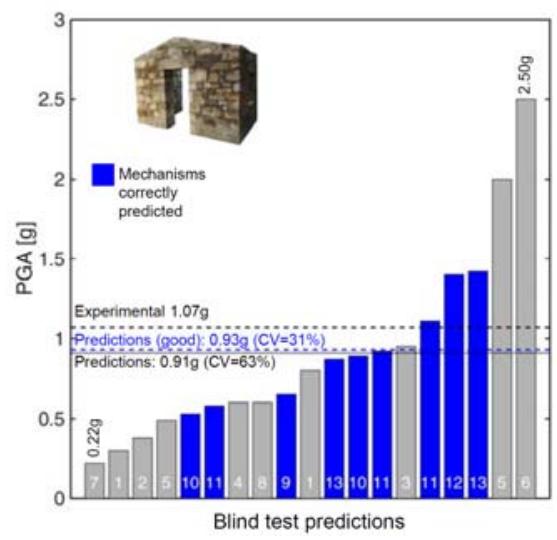

(b)

Figure 4 - Seismic acceleration (PGA) capacity provided by blind predictions:

(a) brick structure; (b) stone structure.

\section{Postdictions}

The shaking table tests were simulated a posteriori by six research groups, making use of various approaches, ranging from analytical methods based on rigid-body mechanisms, to numerical models with finite elements, discrete elements, and combined finite-discrete elements, see de Felice et a. (2017). The previously adopted modelling approaches were not used necessarily again by the same groups, as the time constraints were different. Obviously, at this stage, the experimental results were known, making the task much easier than in blind test predictions. In some cases, e.g., with limit analysis, the failure mechanism was assumed as the starting point of the assessment. Alternatively, the capability of the model to estimate both the failure mechanism and the seismic displacement demand was investigated. The experts that run both predictions and postdictions with the same models had the possibility to update them, e.g., by re-calibrating some parameters, in order to match experimental results.

Nevertheless, the collapse PGA was not provided by many postdictions, which focussed on the assessment of the maximum displacement capacity, the simulation of the displacement response in time or only the identification of the failure mechanism. On the other hand, most postdictions evaluated the seismic displacement demand, which is compared with the displacements recorded in the last tests (at collapse). Taking advantage of the time available for postdictions, the sensitivity of the results to some variables, such as meshing, strength properties, analysis parameters, and input characteristics was also investigated in some cases.

The failure mechanisms provided by postdictions do not differ largely from each other. All of them represented well the torsional response of the structures, whilst the bending strength of the façade resulted underestimated in most cases. Still, this does not allow to ignore the fact that the scatter in the predictions of the experts was too high, independently of the reliability of the single test made in the shaking table. 


\section{Strengthen of earthen structures in Peru}

After the earthquake of Pisco, Peru in 2006 the conservation of local historic adobe buildings received extensive attention. A collaboration between the Minister of Culture in Peru and the Getty Conservation Institute (GCI) was started in order to assess the post-earthquake damage (Cancino et al., 2009).

Next, the Getty Conservation Institute (GCI) initiated the Seismic Retrofitting Project (SRP), as a collaborative project. The ultimate objective of SRP is to provide low-tech seismic retrofitting techniques and easy-to-implement maintenance programs for historic earthen buildings in order to improve their seismic performance while preserving their historic fabric (Cancino et al., 2012). Using Peruvian building prototypes as case studies, the project aims to design and test these techniques; provide guidance for those responsible for implementation, including architects, engineers, and conservators (Cancino et al., 2012); and, work with authorities to gain acceptance of these methods, with the goal of ultimately including them as part of the Peruvian National Building Code.

Four prototype buildings in Peru have been adopted: Casa Arones is a representative example of a two stories mansion, located in the heart of Cusco, constructed at the end of the $16^{\text {th }}$ century; the Church of Kuño Tambo, a religious adobe structure of the $17^{\text {th }}$ century, in the Cusco region; Hotel El Comercio, situated in Lima, a typical three-story patio mansion, L-shaped, built around two interior courtyards, dating back to middle $19^{\text {th }}$ century, and, Ica Cathedral, a highly complex timbermasonry structure of the $18^{\text {th }}$ century, with parts of adobe and brick masonry on the exterior envelope, in the city of Ica. The latter is addressed here and further details are given in Ciocci et al. (2018).

\section{Safety assessment under current conditions}

The Cathedral of Ica is a highly complex structure with a rectangular plan, with a choir loft, a main nave, transept, altar and two lateral aisles. Two sub-structures are evident; an external masonry envelope and an internal timber frame. Built later in a neoclassical style, the main façade is of fired brick masonry, with a thickness of $2.25 \mathrm{~m}$, flanked on both sides with massive bell towers. The lateral walls are of adobe masonry, over a base course of fired brick and rubble stone masonry. The entire timber frame system is comprised by a series of pillars, pilasters and a complex vaulted roof system, with a traditional rendering technique of cane reeds nailed with leather strips, mud plaster and gypsum, known as quincha.

Ica Cathedral has suffered damage due to a series of past earthquakes, namely in 2007 and 2009, with a magnitude 8.0 and 5.8 respectively. The most recent earthquakes led to the collapse of several parts of the vaulted roof and the main dome. The masonry envelope also suffered extensive cracking.

The first experimental vibration mode $(2.84 \mathrm{~Hz})$, see Figure 5 , corresponds to the dominant mode in the transversal direction of the longitudinal side walls of the Cathedral. Both the longitudinal walls of the nave experience a first order out-ofphase excitation with higher intensity in the northern wall, on the transept area. A 
model updating process was conducted, regarding the masonry envelope and the updated material properties.

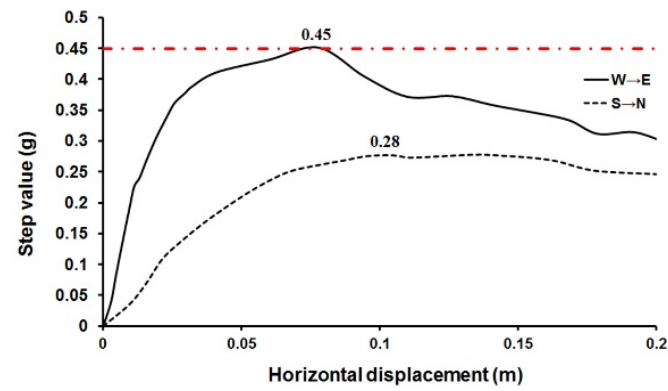

(a)
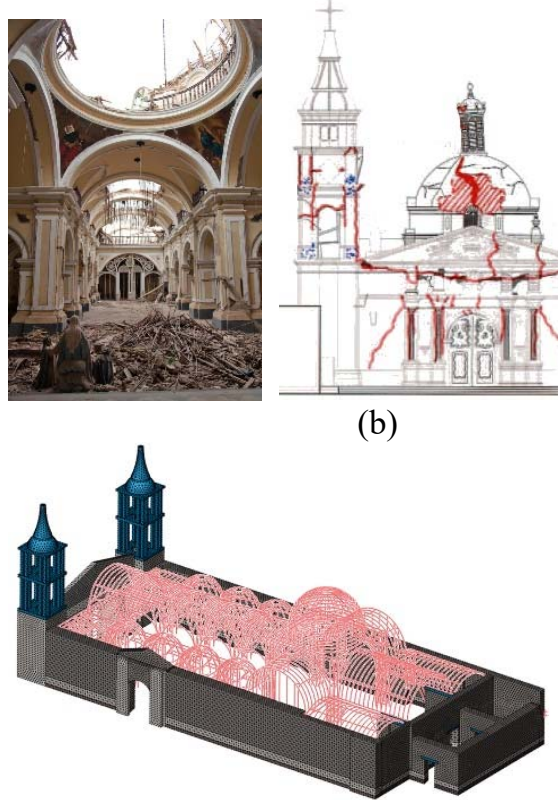

(d)

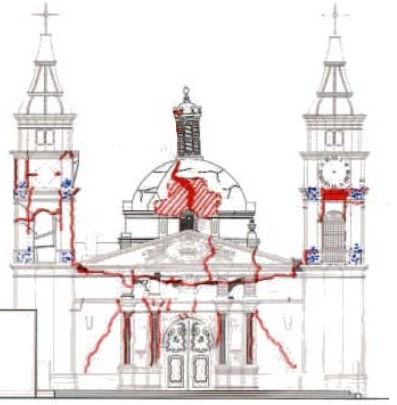

(b)

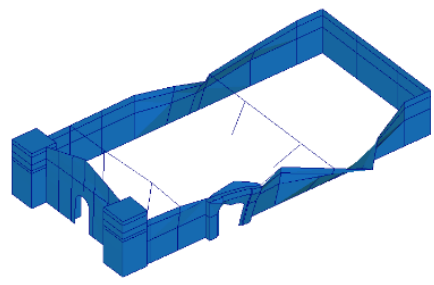

(c)

Figure 5 - Ica Cathedral: (a) Capacity curves for principal directions; (b) crack pattern of east facade (right) and collapsed main dome and barrel vault (left); (c) $1^{\text {st }}$ mode shape from dynamic in-situ tests $(2.84 \mathrm{~Hz})$; (d) FE model in 3D view; (e) plot of maximum principal strain distribution near collapse.

The structural behavior of Ica Cathedral is highly influenced by the interaction between the masonry envelope and the internal timber structure, resulting in a higher lateral capacity, compared to the value obtained from the masonry envelope alone. Out-of-plane stiffness values at early stages are governed by the response of the timber sub-structure. Yet, various stresses in timber connections were found in 
critical state of failure, justifying the partial collapse of the vaulted roof and the central dome. According to the pushover nonlinear analyses, under a mass proportional lateral load, the out-of-plane capacity of the main façade is $0.45 \mathrm{~g}$. Corresponding cracks in the pediment and at connection areas with the choir loft were well correlated with damage in-situ, as shown in Figure 5. The out-of-plane capacity of the north lateral wall is $0.28 \mathrm{~g}$, much lower than the capacity demand of $0.45 \mathrm{~g}$ for the region. Several flexural cracks are formed along the transversal wall, in the interface plane with the rubble stone base course, together with vertical cracks in the intersection with the transept. Those cracks are also present on site.

\section{Traditional strengthening techniques}

A strengthening plan has to be aligned with conservation principles, namely minimal intervention, authenticity and reversibility. The strengthening philosophy and implementation, through traditional techniques, is long proven and present in many historic earthen buildings, though often disregarded in current strengthening practices. It involves the combination of additional mass and stiffness elements; i.e. buttresses and also bracing elements; i.e. corner keys, horizontal keys, bond beams and anchored tie beams. Material compatibility, consolidation and sufficient care in timber connection details are also of vital importance.

Consolidation measures mostly involve the replacement of highly deteriorated adobe and base course masonry parts. The extent of replacement should be clarified from damage mapping and as limited as possible, so as to preserve as much of the historic fabric. Interlocking between old and new masonry parts should also be established.

Reestablishment or addition of buttresses can efficiently address low or compromised out-of-plane capacity and minimize lateral deflections, especially in walls of large spans. Connectivity between the existing earthen walls and the new buttresses can be ensured e.g. by inserting horizontal timber elements at various heights, as shown in Figure 6a and $b$.

For ensuring connectivity and substantial stiffness in corners between orthogonal walls and pillars, orthogonal or diagonal timber keys should be used, Ortega et al. (2017). The insertion should be made at horizontal planes of various elevations and involve mostly the upper parts of walls (Figure $6 \mathrm{c}$ and f). For existing cracks, several processes that respect the historic fabric can be applicable, such as partial replacement of material, stitching, repointing and grout injections, with mud based grouts, Silva et al. (2012). 


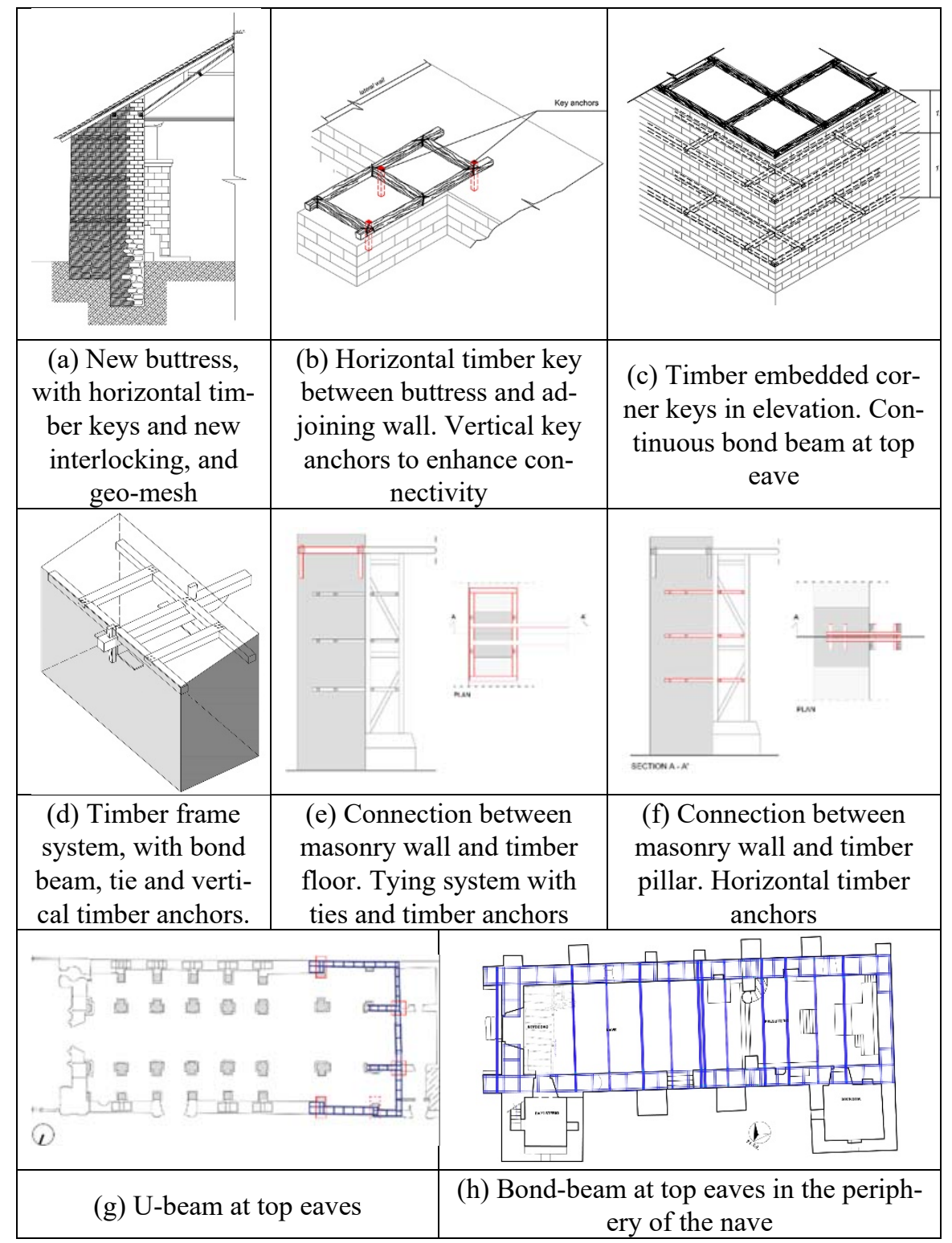

Figure 6: Detailing of traditional strengthening techniques.

Additional lateral restrain, in the case of series of walls in longitudinal alignment, can be offered by means of tie beams. The system is placed at the level of the top eaves, embedded favorably along the entire thickness of the walls. It is subjected to both axial tension and compression, given the dynamic character of seismic loads. Thus, for the system of ties to work, both in tension and compression, an adequate 
anchoring system is needed. A double system of vertical timber anchors, attached close to the interior and exterior surfaces of each wall is proven effective (Figure 6d and e). Though, the overall activation is expected low in case of walls with similar out-of-plane bending stiffness.

Lastly, the implementation of an internal horizontal timber frame system, at the top level and entire thickness of earthen walls, can enhance substantially the capacity under lateral forces. Namely, a bond-beam or U-beam (Figure $6 \mathrm{~g}$ and $\mathrm{h}$ ), which can also serve as support system for roof rafters (wall plates). The whole system can be also connected with a system of tie beams, plates and anchors, forming a combined internal and external timber frame system (Figure 6d). For the tying system to perform, timber elements need to be confined in masonry and subjected to normal vertical stresses, from overlapping masonry parts and roof loads, so that friction or shear action is available.

\section{Safety assessment after strengthening}

The implementation of the strengthening provides a minor increase in stiffness and a large increase in capacity, compared to the current state. The two substructures deform more uniformly, under more rigid connections and the seismic demand of $0.45 \mathrm{~g}$ in the lateral capacity of the north lateral wall is surpassed (Figure 7). Compared to the current state, the capacity in the north-south direction is increased by $100 \%$. Flexural cracking is observed, less in extent and size, over a distributed area of the north-west corner, compared to extensive diagonal and horizontal fragmentations at current state (Figure 7).

\section{Conclusions}

The out-of-plane seismic response for unreinforced earthen and masonry walls are far from trivial. Capturing all aspects of behavior may easily escape the most proficient of modelers. Considerable variance can occur in assessments done by different modelers due to the complexities of nonlinear dynamic response of these truly three-dimensional structures. Because of this, a user must acknowledge that his or her own model is likely to not represent actual response precisely despite the complexity of the model or the analysis tool.

Despite the modeling challenges, structural earthquake engineers should not forget their primary objective - that being to safely assess the capacity of a given building structure with respect to collapse and thus protect the lives of its occupants and the people outside the building. With regard to this objective, some conservatism is much better than the converse. However, excessive conservatism must be circumvented when economies of retrofit solutions may not be practical or the impact on the cultural heritage may be too severe. 


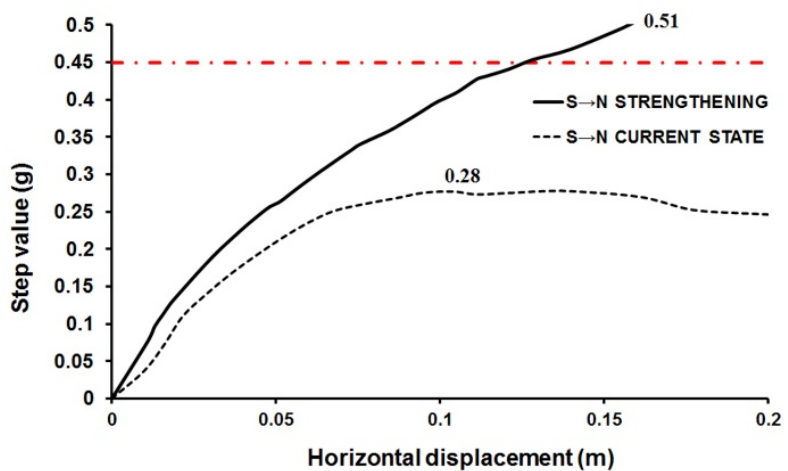

(a)

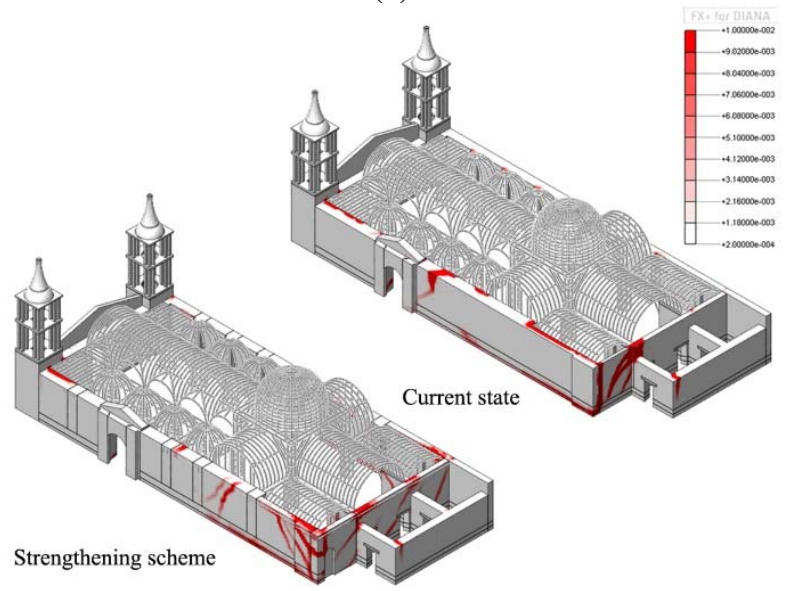

(b)

Figure 7: Ica Cathedral: (a) load-displacement diagram, at the top of the north wall. Note the seismic demand of $0.45 \mathrm{~g}$ (in red); (b) distribution of maximum principal tensile strains at ultimate condition.

The blind test prediction of the out-of-plane seismic capacity of a masonry structure resulted extremely challenging. Predictions of the failure mechanism displayed a large variability, mainly depending on the assumptions on: (i) the effectiveness of the connections between front and side walls; (ii) the bending strength of the façade; and (iii) the in-plane strength of side walls. A method to achieve good estimates appears unavailable, whilst a combination of numerical discrete models and engineering judgement seems able to provide the best guess of the failure mode. Estimates of capacity also differed largely, with an underestimation, in one case significant, of the actual capacity, even when the correct failure mechanism was assumed.

The tools available for researchers and practitioners may significantly contribute to the estimate of seismic safety of existing earthen and masonry structures, but 
appear by themselves not yet sufficient for a refined prediction of the failure mechanism and a reliable estimate of the seismic displacement demand. Still, advanced simulations are the current best guess for engineering applications. Investment on dynamic identification and monitoring and well-designed non-destructive field testing in engineering applications are essential, as they allow calibrating the numerical models and increasing the reliability of structural analysis.

Traditional strengthening techniques can improve the integrity of earthen structures, increase the out-of-plane capacity and redistribute seismic loads, between transversal and longitudinal walls, ensuring a so called 'integral behavior'. Commonly used, traditional strengthening techniques involve the use of buttresses, together with systems of timber strengthening elements, such as bond beams, anchors, corner keys and tie beams.

Under the Seismic Retrofitting Project of the Getty Conservation Institute, USA, extensive inspections, surveys, in-situ testing and nonlinear structural analyses of earthen historic structures, assessed the current state and revealed structural deficiencies. For one case studies, Ica Cathedral, a complete design and assessment of the above-mentioned strengthening solutions are incorporated. For the retrofitted structures, performance criteria and seismic local demands were met, with sufficient safety and acceptable levels of repairable damage.

\section{Acknowledgments}

This work was partly financed in the framework of the Portuguese Public Procurement Code, LOTE 3EC5 - Escola Secundária da Anadia e Gafanha da Nazaré.

\section{References}

Augenti, N. and Parisi, F. 2010. Learning from Construction Failures due to the 2009 L'Aquila, Italy, Earthquake. Journal of Performance of Constructed Facilities, 24:6, 536-555. doi: 10.1061/(ASCE)CF.1943-5509.0000122

Cancino C., Farneth S., Garnier P., Newmann J.V., Webster F. 2009. Damage Assessment of Historic Earthen Buildings after the August 15, 2007, Pisco Earthquake. Research Report, Getty Conservation Institute, Los Angeles.

Cancino C, Lardinois S., D’Ayala D., Ferreira C.F., Dàvila D.T., Meléndez E.V., Santamato L.V.. 2012. Seismic Retrofitting Project: Assessment of Prototype Buildings. Research Report, Getty Conservation Institute, Los Angeles.

Candeias, P.X., Campos-Costa, A., Mendes, N., Costa, A.A., Lourenço, P.B. 2017. Experimental Assessment of the Out-of-Plane Performance of Masonry Buildings Through Shaking Table Tests. Int. J. Archit. Herit., 11(1): 31-58. doi: $10.1080 / 15583058.2016 .1238975$

Ciocci, M.P., Sharma, S., Lourenço, P.B. 2018. Engineering simulations of a supercomplex cultural heritage building: Ica Cathedral in Peru, Meccanica, accepted for publication. 
de Felice, G., de Santis, S., Lourenço, P.B., Mendes, N. 2017. Methods and challenges for the seismic assessment of historic masonry structures, International Journal of Architectural Heritage, 11(1): 143-160.

Ferreira T.M., Costa A.A. and Costa A. 2014. Analysis of the out-of-plane seismic behaviour of unreinforced masonry: A literature review. International Journal of Architectural Heritage, doi: 10.1080/15583058.2014.885996

Lagomarsino, S. 2006. On the vulnerability assessment of monumental buildings. Bulletin of Earthquake Engineering, 4:4, 445-463. doi: 10.1007/s10518-0069025-y

Leite, J., Lourenço, P.B. and Ingham, J.M. 2013. Statistical Assessment of Damage to Churches Affected by the 2010-2011 Canterbury (New Zealand) Earthquake Sequence. Journal of Earthquake Engineering, 17:1, 73-97. doi: $10.1080 / 13632469.2012 .713562$

Lourenço P.B., Mendes N., Ramos L.F. and Oliveira, D.V. 2011. Analysis of masonry structures without box behaviour. International Journal of Architectural Heritage, 5, 369-382. doi: 10.1080/15583058.2010.528824

Lourenço P.B., Mendes N., Costa, A.A., Campos-Costa, A. 2017. Methods and Challenges on the Out-of-Plane Assessment of Existing Masonry Buildings, Int. J. Archit. Herit., 11(1): 1. doi: 10.1080/15583058.2017.1237114

Holzer, T.L. and Savage, J.C. 2013. Global Earthquake Fatalities and Population. Earthquake Spectra, 29:1, 155-175. doi: 10.1193/1.4000106

Mendes, N., Costa, A.A., Lourenço, P.N., Bento, R., Beyer, K., de Felice, G., Gams, M., Griffith, M., Ingham, J., Lagomarsino, S., Lemos, J.V., Liberatore, D., Modena, C., Oliveira, D.V., Penna, A., Sorrentino, L. 2017. Methods and approaches for blind test predictions of out-of-plane behavior of masonry walls: A numerical comparative study, International Journal of Architectural Heritage, 11(1): 59-71.

Noy, I. 2009. The macroeconomic consequences of disasters. Journal of Development Economics, 88:2, 221-231. doi:10.1016/j.jdeveco.2008.02.005

Ortega, J., Vasconcelos, G., Rodrigues, H., Correia, M., Lourenço, P.B. 2017. Traditional earthquake resistant techniques for vernacular architecture and local seismic cultures: A literature review, Journal of Cultural Heritage. doi: 10.1016/j.culher.2017.02.015

Parker, R., Little, K. and Heuser, S. 2007. Development actions and the rising incidence of disasters. IEG evaluation brief, no. 4. Washington, DC: World Bank. Available at: http://documents.worldbank.org/curated/en/2007/06/11918676/development -actions-rising-incidence-disasters

Penna, A., Morandi, P., Rota, M., Manzini, C. F., da Porto, F., and Magenes, G. 2014. Performance of masonry buildings during the Emilia 2012 earthquake. Bulletin of Earthquake Engineering, 12(5): 2255-2273. doi: 10.1007/s10518013-9496-6

Silva, R.A., Schueremans, L., Oliveira, D.V., Dekoning, K., Gyssels, T. 2012. On the development of unmodified mud grouts for repairing earth constructions: rheology, strength and adhesion. Materials and Structures, 45(10): 1497-1512 
Sorrentino, L., D'Ayala, D., de Felice, G., Griffith, M., Lagomarsino, S., and Magenes, G. 2016. Review of out-of-plane seismic assessment techniques applied to existing masonry buildings. Int. J. Archit. Herit., 11(1): 2-21. doi: $10.1080 / 15583058.2016 .1237586$ 